\title{
Pengaruh Karakteristik Demografis, Klinis dan Laboratorium pada Neonatus dengan Hiperbilirubinemia
}

\section{The Role of Demographic, Clinical and Laboratory Characteristics in Infant with Hyperbilirubinemia}

\author{
Eko Sulistijono, Ingga Gebyarani, M Fahrul Udin, Brigitta Corebima, Siti Lintang K \\ Laboratorium Ilmu Kesehatan Anak Rumah Sakit Umum Dr. Saiful Anwar Malang
}

\begin{abstract}
ABSTRAK
Kejadian ikterus pada bayi aterm di beberapa rumah sakit di Indonesia bervariasi antara 13,7-85\%. Jenis ikterus patologis dapat menyebabkan hiperbilirubinemia. Penelitian ini dilakukan untuk mengetahui pengaruh karakter demografi, usia klinis dan laboratorium terhadap bayi hiperbilirubinemia yang dirawat di rumah sakit umum Dr. Saiful Anwar, Malang. Penelitian ini merupakan penelitian observasional retrospektif. Data-data diambil dari rekam medis sejak Januari 2010Oktober 2010. Dari analisis regresi multiple dengan confident interval 95\% (Cl 95\%) dan p<0,05, ada empat faktor signifikan yang mempengaruhi tingkat bilirubin. Faktor-faktor yang berpengaruh adalah instrumen persalinan $(p=0,006)$, asfiksia $(p=0,013)$, kadar hemoglobin $(p=0,047)$, dan ASI eksklusif $(p=0,049)$. Asfiksia, persalinan dengan instrumen, ASI eksklusif, dan tingkat hemoglobin merupakan faktor penting yang mempengaruhi tingkat bilirubin pada neonatus
\end{abstract}

Kata Kunci: Hiperbilirubinemia, jaundice, neonatus

\section{ABSTRACT}

In some hospital in Indonesia, icterus incidence in mature infant varies between $13,7-85 \%$. Pathologic icterus can lead to hyperbilirubinemia. The purpose of this study was to investigate the role of demographic, clinical and laboratory characteristic in hyperbilirubinemia infant treated at Syaiful Anwar General Hospital, Malang. A retrospective observational study was carried out, data taken from the medical record since January 2010-October 2010. Using multiple regression analysis with confident interval 95\% (Cl 95\%) and $p<0,05$, there were four significant factors that affected bilirubin levels. The factors were instrumental delivery $(p=0,006)$, asphyxia $(p=0,013)$, hemoglobin level $(p=0,047)$ and exclusive breastfeeding $(p=0,049)$. Asphyxia, instrumental delivery, exclusive breastfeeding and hemoglobin level were the significant factors affecting bilirubin levels in neonates.

Keywords: Hyperbilirubinemia, jaundice, neonates

Jurnal Kedokteran Brawijaya, Vol. 26, No. 4, Agustus 2011; Korespondensi: Eko Sulistijono. Laboratorium Ilmu Kesehatan Anak Rumah Sakit Umum Dr. Saiful Anwar Malang, Jl. Jaksa Agung Suprapto No. 2 Malang Tel. (0341)366242 Email: ika_fkub@yahoo.com 


\section{PENDAHULUAN}

Di Indonesia insiden ikterus pada bayi aterm di beberapa rumah sakit (RS) pendidikan, antara lain: RS dr. Cipto Mangunkusumo, RS dr. Sardjito, RS dr. Soetomo dan RS dr. Kariadi, angka bervariasi dari $13,7-85 \%$ (1). Saat ini belum terdapat data mengenai angka kejadian hiperbilirubinemia, baik pada neonatus cukup bulan maupun kurang bulan di RS Saiful Anwar Malang. Bayi dengan ikterus berpotensi menjadi hiperbilirubinemia, terlebih bila terdapat keadaan patologis yang mendasari.

Hiperbilirubinemia adalah istilah yang dipakai untuk ikterus neonatorum setelah ada hasil laboratorium yang menunjukkan peningkatan kadar serum bilirubin. Hiperbilirubinemia fisiologis yang memerlukan terapi sinar, tetapi tergolong non patologis sehingga disebut excessive physiological jaundice. Kondisi hiperbilirubinemia patologis (non physiological jaundice) ditegakkan apabila kadar serum bilirubin terhadap usia neonatus $>95 \%$ menurut Normogram Bhutani (2-4). Bayi dinyatakan menderita bilirubinemia apabila kadar bilirubin total $>12 \mathrm{mg} / \mathrm{dL}$ (>205 $\mu \mathrm{mol} / \mathrm{L}$ ) pada bayi cukup bulan, sedangkan pada bayi kurang bulan bila kadarnya $>10 \mathrm{mg} / \mathrm{dL}$ (>171 $\mu \mathrm{mol} / \mathrm{L}$ ) (4). Bayi dengan bilirubin total $25-30 \mathrm{mg} / \mathrm{dL}$ (428-513 $\mu \mathrm{mol} / \mathrm{L})$ mempunyai risiko tinggi terserang toksisitas bilirubin yang dapat menyebabkan ensefalopati bilirubin atau Kern ikterus. Hiperbilirubinemia berat dapat menekan konsumsi $\mathrm{O}_{2}$ dan menekan oksidasi fosforilasi menyebabkan kerusakan sel-sel otak, berakibat disfungsi neuronal, dan ensefalopati $(4,5)$. Bayi-bayi dengan keadaan tersebut berisiko mengalami kematian atau kecacatan di kemudian hari.

Hiperbilirubinemia berhubungan dengan inkompatibilitas golongan darah $\mathrm{ABO}$, breast milk jaundice, sepsis, polisitemia, prematuritas, berat badan lahir rendah, cara persalinan dengan tindakan yang memicu terjadinya hematom sefal dan asfiksia (6). Oleh karena itu faktorfaktor yang berperan pada kejadian hiperbilirubinemia perlu dikaji lebih lanjut. Tujuan penelitian ini untuk mengetahui pengaruh karakteristik demografis, klinis, dan laboratorium terhadap kadar bilirubin pada neonatus.

\section{METODE}

Penelitian dilakukan dengan mengkaji data rekam medis neonatus yang memenuhi kriteria inklusi dan eksklusi di RS Saiful Anwar Malang sejak bulan Januari 2010 sampai dengan Oktober 2010. Data yang dikaji meliputi jenis kelamin, usia ibu, berat badan lahir, usia kehamilan, cara persalinan, kondisi asfiksia, sepsis, pemberian ASI eksklusif, pemeriksaan kadar hemoglobin, albumin sebagai faktor risiko serta bilirubin total, bilirubin terkonjugasi dan bilirubin tak terkonjugasi sebagai keluaran.

Data pasien dipilih dengan kriteria inklusi: pasien yang memiliki kadar bilirubin total serum $\geq 10 \mathrm{mg} / \mathrm{dl}$ dan kriteria eksklusi adanya kolestasis atau kadar bilirubin direct $\geq 20 \%$ dari bilirubin total dan data rekam medis tidak lengkap. Dari 432 data pasien, terdapat 102 data pasien yang memenuhi kriteria inklusi. Analisis statistik menggunakan SPSS 15 dengan uji regresi berganda metode forward. Sebelum dilakukan analisis regresi berganda, terlebih dahulu telah dilakukan 4 uji asumsi klasik yang meliputi uji normalitas data, uji non heteroskedastisitas, uji autokorelasi dan multikolinieritas (7). Hasil semua uji menunjukkan asumsi klasik telah terpenuhi.

\section{HASIL}

Rata-rata kadar bilirubin total serum $15,45 \pm 5,14$ gram/dl. Karakteristik subjek penelitian menunjukkan proporsi jenis kelamin yang hampir sama antara laki-laki dan perempuan, 33 pasien $(32,4 \%)$ mengalami sepsis dan $35,3 \%$ asfiksia. Persalinan spontan lebih banyak daripada persalinan dengan tindakan dengan berat badan lahir rata-

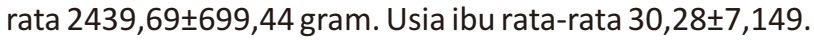
Usia kehamilan rata-rata $36,18 \pm 3,79$. Pemeriksaan laboratorium menunjukkan kadar $\mathrm{Hb} 13,52 \pm 2,25$, kadar albumin $3,47 \pm 0,42$. Tabel 1 menunjukkan data karakteristik seluruh bayi yang diikutkan dalam penelitian.

Tabel 1. Gambaran karakteristik demografis, klinis dan laboratoris

\begin{tabular}{lll}
\hline \multicolumn{1}{c}{ Karakteristik } & \multicolumn{1}{c}{$\mathbf{N = 1 0 2}$} & p \\
\hline Jenis kelamin (\%) & & 0,274 \\
- Laki-laki & $49(48 \%)$ & \\
- Perempuan & $53(52 \%)$ & \\
Usia ibu (tahun) & $30,28 \pm 7,149$ & 0,443 \\
Usia kehamilan (minggu) & $36,18 \pm 3,79$ & 0,713 \\
Berat badan lahir (gram) & $2439,69 \pm 699,44$ & 0,852 \\
Cara lahir & & 0,006 \\
- Spontan & $66(64,7 \%)$ & \\
Tindakan & $36(35,3 \%)$ & \\
Asfiksia & $12(35,3 \%)$ & 0,0013 \\
ASI eksklusif & $19(18,6 \%)$ & 0,049 \\
Sepsis & $33(32,4 \%)$ & 0,407 \\
Kadar Hb (g/dl) & $13,52 \pm 2,25$ & 0,047 \\
Kadar Albumin (g/dl) & $3,47 \pm 0,42$ & 0,254 \\
\hline
\end{tabular}

Berdasarkan, hasil analisis multiple regression dengan interval kepercayaan 95\% (Cl 95\%) dan $\mathrm{p}<0,05$, terdapat 4 faktor yang signifikan mempengaruhi kadar bilirubin, yaitu: cara lahir dengan tindakan $(p=0,006)$, asfiksia $(p=0,013)$, kadar Hb $(p=0,047)$ dan ASI eksklusif $(p=0,049)$.

Tabel 2. Hasil uji regresi

\begin{tabular}{llllll}
\hline \multicolumn{1}{c}{ Variabel } & $\begin{array}{c}\text { Koefisien } \\
\text { regresi (b) }\end{array}$ & Std. Error & Beta & $\mathbf{T}_{\text {hitung }}$ & Sig \\
\hline Konstanta & 15,978 & 8,426 & & 1,896 & 0,061 \\
Jenis kelamin & $-1,025$ & 0,931 & $-0,100$ & $-1,100$ & 0,274 \\
Usia gestasi & 0,080 & 0,217 & 0,059 & 0,369 & 0,713 \\
BB lahir & $2,1^{*} 10^{-4}$ & 0,001 & 0,029 & 0,187 & 0,852 \\
Sepsis & 0,878 & 1,053 & 0,080 & 0,833 & 0,407 \\
Kadar Hb & $-0,427$ & 0,212 & $-0,187$ & $-2,015$ & 0,047 \\
Asfiksia & 4,051 & 1,604 & 0,255 & 2,526 & 0,013 \\
ASI eksklusif & 2,529 & 1,268 & 0,193 & 1,996 & 0,049 \\
Cara lahir & $-3,082$ & 1,086 & $-0,288$ & $-2,839$ & 0,006 \\
Albumin & 1,339 & 1,166 & 0,110 & 1,148 & 0,254 \\
Usia ibu & 0,055 & 0,072 & 0,077 & 0,770 & 0,443 \\
\hline
\end{tabular}

R Square $\quad=0,264$

$\mathrm{R}$ Square (Adjusted) $\quad=0,184$

F hitung $\quad=3,271$

Sign $\mathrm{F} \quad=0,000$ 


\section{DISKUSI}

Penelitian ini menunjukkan bahwa persalinan dengan tindakan, asfiksia, kadar $\mathrm{Hb}$ dan pemberian ASI eksklusif terbukti secara signifikan mempengaruhi kadar bilirubin pada neonatus. Penyebab peningkatan kadar hiperbilirubinemia pada bayi baru lahir diantaranya karena produksi bilirubin yang berlebihan, penurunan uptake bilirubin oleh sel hati, penurunan konjugasi bilirubin dan gangguan ekskresi bilirubin. Sebagian besar (70-80\%) bilirubin terbentuk dari pemecahan hemoglobin dari eritrosit di sistem retikuloendotelial. Risiko hiperbilirubinemia meningkat pada bayi yang mendapat ASI, bayi kurang bulan, dan bayi yang mendekati cukup bulan. Neonatal hiperbilirubinemia terjadi karena peningkatan produksi atau penurunan clearance bilirubin dan lebih sering terjadi pada bayi imatur(8). Hiperbilirubinemia yang signifikan dalam 36 jam pertama biasanya disebabkan karena peningkatan produksi bilirubin (terutama karena hemolisis), karena pada periode ini hepatic clearance jarang memproduksi bilirubin lebih dari $10 \mathrm{mg} / \mathrm{dL}$. Peningkatan penghancuran hemoglobin $1 \%$ akan meningkatkan kadar bilirubin 4 kali lipat (9).

Cara persalinan dengan tindakan (sectio cesarea, total ekstraksi maupun vacum ekstraksi) dapat menyebabkan cephal hematoma maupun facial bruising (9). Analisis multivariat dengan regresi logistik pada penelitian Newmann dkk menunjukkan usia kehamilan, ASI eksklusif, ras Asia, cephal hematoma dan usia ibu $\geq 25$ tahun merupakan faktor risiko yang signifikan terhadap hiperbilirubinemia (10). Penelitian ini menunjukkan persalinan dengan tindakan menyebabkan kejadian hiperbilirubinemia pada neonatus.

Penelitian sebelumnya mendapatkan hubungan positif antara terjadinya hiperbilirubinemia dengan berat badan lahir rendah, pemberian ASI, ketuban pecah dini, infeksi, polisitemia, penggunaan obat saat hamil, serta persalinan dengan tindakan, sedangkan ras oriental dan penggunaan oksitosin tidak berpengaruh (9). Penelitian oleh Alpay dan Triasih dkk menjelaskan faktor-faktor yang berhubungan dengan peningkatan kadar bilirubin seperti hematokrit, hemoglobin, berat badan lahir, cara persalinan,

\section{DAFTAR PUSTAKA}

1. Hutahaean B and Putranti AH. Neurodevelopmental Disorder Risk in Babies with History of Hyperbilirubinemia. Pediatrica Indonesiana. 2008; 48(2): 93-98.

2. Gomella TL. Hyperbilirubinemia Direct (Conjugated) and Indirect (Unconjugated). In: Neonatology, Management, Procedures, on Call Problems, Diseases and Drugs 4th edition. New York: The McGraw-Hill; 2008.

3. Camilia RM and Cloherty JP. Neonatal Hyperbilirubinemia. In: Cloherty JP (Ed). Manual of Neonatal Care 5th edition. Philadelphia: Lippincott Williams and Wilkins; 2004; p. 185-221.

4. Sylviati MD, Fatimah I, Agus H, dan Risa E. Pedoman Diagnosis dan Terapi. Surabaya: Bagian/SMF. IImu Kesehatan Anak FK UNAIR-RSU Dr. Soetomo; 2004.

5. Uhudiah U dan Oktavia D. Pemberian Terapi Sinar pemberian ASI dan kebiasaan merokok tidak bermakna $(10,11)$.

Penelitian Chou et al dengan analisis regresi logistik membuktikan bahwa kehamilan tidak cukup bulan, cara pemberian $\mathrm{ASI}$, ras bukan kulit hitam mempunyai hubungan dengan tingginya insidensi neonatal hiperbilirubinemia (12). Pada penelitian ini pemberian ASI juga berpengaruh pada peningkatan kadar bilirubin. $B$ glukoronidase yang tinggi pada ASI mengakibatkan unconjugated bilirubin meningkat kembali ke sirkulasi enterohepatik.

Satu gram hemoglobin dapat menghasilkan $35 \mathrm{mg}$ bilirubin tak terkonjugasi. Kecepatan produksi bilirubin pada bayi 2,5 kali kecepatan produksi bilirubin orang dewasa, oleh karena jumlah eritrosit pada bayi baru lahir lebih banyak daripada orang dewasa dan rata-rata umur eritrosit pada bayi baru lahir lebih pendek yaitu 80-90 hari sedangkan orang dewasa 120 hari (13). Penelitian ini menunjukkan regresi negatif pada kadar $\mathrm{Hb}$, semakin rendah kadar $\mathrm{Hb}$, maka semakin tinggi kadar bilirubin. Hal tersebut dapat disebabkan oleh kondisi bayi dengan infeksi, perdarahan antepartum atau anemia pada ibu.

Penelitian ini menunjukkan kadar albumin tidak bermakna terhadap peningkatan kadar bilirubin karena rasio bilirubin dibanding albumin hanya 4,45. Masalah timbul apabila produksi bilirubin ini terlalu berlebihan atau konjungasi dengan albumin untuk masuk ke hepar menurun sehingga terjadi akumulasi di dalam darah.

Sawar darah otak (SDO) mengatur masuknya bilirubin ke dalam otak dan mencegah difusi zat-zat tertentu dari pembuluh darah ke jaringan otak. Kerusakan SDO meningkatkan permeabilitas otak terhadap bilirubin. Beberapa faktor yang menyebabkan kerusakan SDO, yang selanjutnya meningkatkan risiko terjadinya ensefalopati bilirubin akut pada bayi antara lain: asfiksia/hipoksia, asidosis, hipoperfusi, hipoosmolaritas, infeksi/sepsis, hipoglikemia, trauma kepala, prematuritas, dan sebagainya $(14,15)$. Dapat disimpulkan persalinan dengan tindakan, asfiksia, kadar $\mathrm{Hb}$ rendah dan pemberian ASI eksklusif menyebabkan peningkatan kadar bilirubin pada neonatus.

Berdasarkan Penilaian Klinis pada Neonatus dengan Hiperbilirubinemia. Kongres Nasional VIII Perinasia and Simposium Internasional. Medan: Perinasia; 2003: hal. 74-81.

6. Kliegman RM. Jaundice and Hyperbilirubinemia in the Newborn. Philadelphia: WB Saunders; 2004.

7. Santoso S. Buku Statistik Parametrik. Cetakan Keempat. Jakarta: PT Elex Media Komputindo; 2004.

8. Sciuto $\mathrm{M}$, Bertino $\mathrm{G}$, Zocco $\mathrm{M}$, and Vecchio I. Incidence and Causes of Neonatal Hyperbilirubinemia in $A$ Center of Catania. Therapeutics and Clinical Risk Management. 2009; 5: 247-250.

9. Muchayat $\mathrm{S}$ dan Juliwati. Profil Kadar Bilirubin pada Bayi Baru Lahir Sehat dengan Ikterus di Rumah Sakit Dr.Sardjito Yogyakarta. Jurnal Kedokteran Yarsi. 2006; 14 (3): 177-181.

10. Alpay F, Sarici SU, Tosuncuk HD, Serdar MA, Inanc N, and Gokcay E. The Value of First Day Bilirubin 
Measurement in Predicting the Development of Significant Hyperbilirubinemia in Healthy Term Newborns. Pediatrics. 2000; 106(2): e16.

11. Triasih R, Haksari E, dan Surjono A. Kadar Bilirubin 24 Jam Pertama sebagai Faktor Prediksi Hiperbilirubinemia pada Bayi Cukup Bulan yang Sehat. Ilmu Kedokteran Berkala. 2002; 34(3): 141148.

12. Chou SC, Palmer RH, Ezhuthachan S, et al. Management of Hyperbilirubinemia in Newborns: Measuring Performance by Using A Benchmarking Model. Pediatrics. 2003; 112(6): 1264-1273.
13. Newmann TB, Xiong B, Gonzales VM, and Escobar GJ. Prediction and Prevention of Extreme Neonatal Hyperbilirubinemia in a Mature Health Maintenance Organization. Archives of Pediatrics and Adolescent Medicine. 2000; 154(11): 1140-1147.

14. Dennery PA, Seidman DS, and Stevenson DK. Neonatal Hyperbilirubinemia. The New England Journal of Medicine. 2001; 344: 581-590.

15. Porter ML and Dennis BL. Hyperbilirubinemia in The Term Newborn. American Family Physician. 2002; 65(4): 599-606. 